\title{
波峯線に平行度鉛直断面内に設置された傾斜円柱に 作用する波力について
}

重村利幸*. 西村健二**. 竹内俊雄***

\section{1. 緒言}

直立円柱または水平円柱に作用する波力に関しては, 従来多くの実験的研究がなされ，かなりの知見が得られ ている。しかしながら，傾斜円柱に作用する波力につい ては未だ十分な知見は得られていない，著者らは波の進 行方向之平行な鉛直断面内記設置した小口径の傾斜円柱 に作用する波力について, 既に幾つかの研究成果を発表 してきたが1),2), 本研究は波峯線に平行な鉛直断面内に 設置した小口径の傾斜円柱に関する一連の実験成果であ る.

本論文では特に以下の 3 点について論じる.

1）傾斜円柱に対する波力算定式の誘導ならびに同算定 式の評価.

2）傾斜円柱に作用する最大 in-line force と最大 transverse force $の$ 比.

3）作用波と in-line force との位相差.

\section{2. 波力算定式の誘導および各係数の算定法}

図一1は波峯線に平行な鉛直断面内で鉛直軸に対して 任意の角度, $\theta$ だけ傾斜させて設置した小口径円柱の設 置状沉を示すスケッチである.

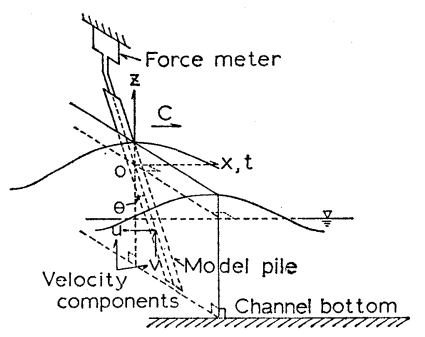

图一1 円柱模型の設置状況

さて，任意時刻， $t$ に打いてこの様な傾斜円柱に作用 する全 in-line force, $F_{X t}(t)$ は水粒子の水平分速度, $u$ 抢よび同加速度, $\dot{u}$ による in-line force, $F_{X u}(t)$ と水 粒子の垂直分速度, $v$ による transverse force, $F_{T v}(t)$

\footnotetext{
* 正会員 Dr. Eng. 防衛大学校助教授 土木工学教室

** 正会員海上自衛隊幕缭監部管理浬

*** 正会員 工博防衛大学校教授 土木工学教室
}

の和として評価されるであろう。一方，同傾斜円柱に作 用する全 transverse force, $F_{T t}(t)$ は $u$ による transverse force, $F_{T u}(t), v$ 拉よび同加速度, $\dot{v}$ による in-line force, $F_{X v}(t)$ 打よび波面変動によって生ずる浮力項, $F_{B}(t)$ の 和として評価されるであるう。従って，上述の各 in-line force 打よび transverse force の算定にモリソン式就よ び揚力式の考方方がそのまま適用できると仮定すれば， $F_{X t}(t)$ および $F_{T t}(t)$ はそれぞれ次式で評価される。

$$
\begin{aligned}
& F_{X t}(t)=F_{X u}(t)+F_{T v}(t) \\
& =C_{D u} \cdot \frac{1}{2} \rho D \int_{-\hbar}^{\eta}|u| u \frac{d z}{\cos \theta} \\
& +C_{M \dot{u}} \frac{1}{4} \rho \pi D^{2} \int_{-h}^{\eta} \dot{u} \frac{d z}{\cos \theta} \\
& +C_{T v} \cdot \frac{1}{2} \rho D \int_{-h}^{\eta}(v \sin \theta)^{2} \frac{d z}{\cos \theta} \cdots \\
& F_{T t}(t)=F_{T u}(t)+F_{X v}(t)+F_{B}(t) \\
& =C_{T: u} \cdot \frac{1}{2} \rho D \int_{-h}^{\eta} u^{2} \cdot \frac{d z}{\cos \theta} \\
& +C_{D v} \frac{1}{2} \rho D \int_{-h}^{\eta}|v \sin \theta| v \sin \theta \frac{d z}{\cos \theta} \\
& +C_{M \dot{v}} \frac{1}{4} \rho \pi D^{2} \int_{-\hbar}^{\eta}(\dot{v} \sin \theta) \frac{d z}{\cos \theta} \\
& +\frac{1}{4} \rho g \pi D^{2} \eta \tan \theta
\end{aligned}
$$

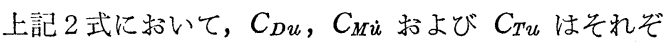
れ $u$ 少よび $\dot{u}$ による傾斜円柱の抗力係数, 質量係数扔 よび揚力係数を示し， $C_{D v}, C_{M v}$ および $C_{T v}$ はそれぞ れ $v$ 打よび $\dot{v}$ による抗力係数, 質量係数打よび揚力係 数を示す.ただし，これら各係数值は全て冠水水深によ る平均值である。一方， $h, \eta, \rho$ および $D$ は乞れぞれ， 水深, 波面水位, 水の密度打よび円柱外径学示す.

さて，(1）および（2）式から傾斜円柱に作用する全 in-line force 拉よび transverse force を算定するために は，円柱周辺の流れ場の推定ならびに各保数值の選定が 必要となる，この内，円柱周辺の流れ場は適当な波動理 論から推定することにすれば，各係数值は害験的に決定 される. 従来, 各係数值の決定には種々の方法が提案さ れているが，これらの方法は各係数值が time-independent であると仮定して定める方法と各係数值が time-de- 
pendent と仮定して定める方法とに大別される. 本研究 では，これら両カテゴリーに属する方法を用いて各係数 値を算定することにする。

先づ, time-independent な係数值を決定するためには （1）および（2）式中にそれぞれ 3 個の未知係数が含まれ ているため, 下記の 3 点法を用いる. この方法は, 周期 内の相異なる 3 つ位相点において (1) および (2) 式か らそれぞれ 3 個の方程式を求め, 次いでこれら各組の方 程式を連立方程式として解くことにより各係数值を決め る方法である、また， 1 周期， $T$ 内を $N$ 等分し，各分 割点における諸データーに基づいて最小自乗法から各係 数值を定める方法も併せて用いることにする.

一方, time-dependent な係数值の決定には Al-Kazily 法3) 修正した変形 Al-Kazily 法を用いることにする。 この方法は先きの $N$ 等分した各分割点のうち，相隣る 3 つの位相, $(3 I-3) \Delta t,(3 I-2) \Delta t$ および $(3 I-1) \Delta t$ で 各係数值が一定值を保つと仮定することにより，(1) 示 よび（2）式からそれぞれ 3 個の方程式を得る. 次いで, これら各組の方程式をとれぞれ連立方程式として解くこ とにより, 中間位相点, $(3 I-2) \Delta t$ における各係数值を 決定する.ここに， $\Delta t$ は $T / N$ を示すので, 分割数, $N$ を十分に大きくとった上で 1 周期にわたり同上の繰作を くりかえせば，周期内の任意の位相に括ける各係数值を 決定することができる.

\section{3. 実験装置および方法}

実験には長さ $12.0 \mathrm{~m}$, 幅 $4.5 \mathrm{~m}$, 深さ $1.2 \mathrm{~m}$ の平面 造波水槽を使用した。同水槽上には水槽の長軸方向に走 行する移動台車が付設されている。この移動台車の主桁 下縁中央部には, 波峯線に平行な鉛直断面内で鉛直軸に 対して左右にそれぞれ $90^{\circ}$ まで回転できる波力計固定装 置を剛接した。な拉, 波力計には互に直交する 2 軸方向 の力, $F_{X}$ 就よび $F_{Y}$ ならびに $y$ 軸のまわりのモー> ント， $M_{Y}$ を同時に検出できる 3 分力計（日章電機(株) 製，LMC-3501-1）を用いることにし，これを所定の方 向に精確に合せた後, 上記固定装置に装着した。

さて，表一1 は本実駼に使用する円柱模型の諸元なら びに実験ケースを示す。な抢, 各円柱の上端部は 3 分力 計に装着できる様に加工し，下端部はビニールシートで 密閉した.

実験は造波機の前方 $6 \mathrm{~m}$ の位置で実施した。なお， 円柱取付時に扔ける円柱下端と水槽底との間淂はいずれ も約 $1 \mathrm{~cm}$ とした。一方，作用波の諸特性を計測するた めに造波板の前方 $5 \mathrm{~m}$ の位置および円柱真横に容量式 波高計を設置した。実験は合計 147 通り実施したが，各 実験ケースに沶いては作用波の諸特性ならびに傾斜円柱 に作用する全 in-line force 拉よび全 transverse force を 電磁オシログラフ上に同時記録した。
表一1 模型円柱の諸元および実験ケース

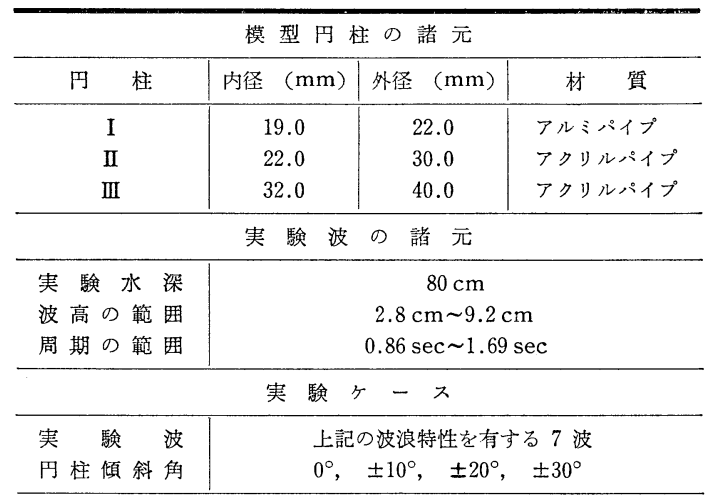

\section{4. 実験結果および考察}

円柱周辺の流れ場の推定には先きに実施した一連の研 究1),2) との関連もあり, ストークス波の第 3 次近似式を 用いた。 また, 最小自乗法ならびに変形 Al-Kazily 法に よる倸数値の決定等に必要な 1 周期内の分割数, $N$ は 100 とした. 以下, 緒言で述べた 3 項目についての解析 結果について順次, 論じてゆく.

\section{1 波力算定式の評価}

(1) In-line force 算定式の評価

図-2 は前述の 3 点法および最小自乘法で求めた timeindependent な各係数値を用い，(1) 式より計算した全 in-line force, $F_{X t 3}(t)$ および $F_{X t l}(t)$ と実測した in-line force, $F_{X m}(t)$ との比較例定示す.

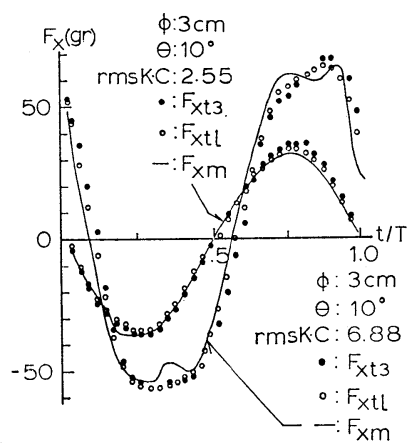

図一2 $F_{X t}(t)$ と $F_{X m}(t)$ の比較例 (Time-independentな係数值を用いた場合)

全実験例につき同様な比較を行なった結果, $\mathrm{rms} K \cdot C$ 数が 3 以下の場合には両計算波力とも周期内のほぼ全位 相において実測波力と比較的よく符号するが， $\mathrm{rms} K \cdot C$ 数が 6 以上の場合には $F_{X t 3}(t)$ 打よび $F_{X t l}(t)$ は両者が 極值定とる位相の近傍に数いて $F_{X m}(t)$ に追従し得なく なることが判った．次に，乙れら計算波力と実測波力と の符合性を定量的に検討するために，下に示す式から雨 波力の分散度, $\delta F_{X}$ 算出した。 


$$
\begin{aligned}
& \delta F_{X} \\
& =\frac{\sqrt{\sum_{I=1}^{101}\left\{F_{X t}[(I-1) T / 100]-F_{X m}[(I-1) T / 100]\right\}^{2} / 101}}{\left(F_{X m}\right)_{\max }-\left(F_{X m}\right)_{\min }}
\end{aligned}
$$

図一3 は $\delta F_{X}$ と $\mathrm{rms} K \cdot C$ 数との関係を $\theta$ 毎にプロ ットしたものである. 図中, $\delta F_{X t 3}$ は $F_{X t 3}(t)$ の $F_{X m}(t)$ からの，また $\delta F_{X t l}$ は $F_{X t l}(t)$ の $F_{X m}(t)$ からの各分散 度を示す。この図から以下の諸点が明らかになった。

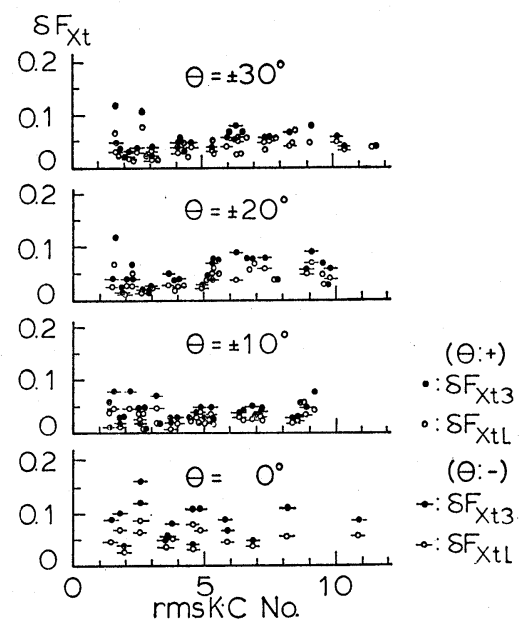

図一3 $F_{X t}(t)$ の $F_{X m}(t)$ からの分散度 (Timeindependent な係数值を用いた場合)

a）直円柱の場合には，傾斜円柱の場合に比し両分散 度とも大きい值をとり, しかも両分散度は $\mathrm{rms} \cdot K \cdot C$ 数 の值に関係なく，ほぼ $10 \%$ 程度の一定值をとる。

b）傾斜円柱の場合には， $\theta$ の大きさに関係なく両分 散度は $\mathrm{rms} K \cdot C$ 数の増大に伴ない同様な増大を示し, $\mathrm{rms} K \cdot C$ 数が 10 程度になると約 $10 \%$ の值となる。

c) $\delta F_{X t l}$ は $\theta$ および $\mathrm{rms} K \cdot C$ 数の全領域において $\delta F_{X t 3}$ より小さい值となる.

次に, time-dependent な係数值を用いて算出した計算 in-line force について同様な解析を試夕る。ただし，変 形 Al-Kazily 法では周期内の全位相に扔いて計算波力が 実測波力に一致するよう各係数值を決めるので，同法に より定めた係数值をそのまま用いて波力を算出するこ とは意味がない，とこで，これら各係数值は先きの研 究1),2) で実施したと同様に，それぞれ作用波周波数の整 数倍の周波数を有する数個の有意周波数成分から成るフ 一リエー級数に展開・近似させ，これら各近似係数を用 いて計算 in-line force, $F_{X t F}(t)$ 学算出した。

図一4 は $F_{X t F}(t)$ と $F_{X m}(t)$ の比較例を示す.

全実験例について同様な比較を行なった結果, $F_{X t F}(t)$ は周期内の全位相に括いて, $\mathrm{rms} K \cdot C$ 数抒よび $\theta$ に関 係なく $F_{X m}(t)$ と極めてよく符合することが判った.

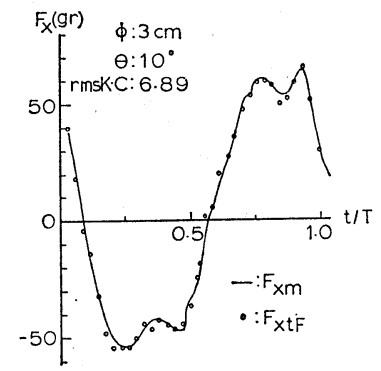

图-4 $F_{X t}(t)$ と $F_{X m}(t)$ の比較例 (Time-dependent な係数值を用いた場合)

次いで, $F_{X t F}(t)$ についても (3) 式にならって $F_{X m}(t)$ からの分散度, $\delta F_{X t F}$ を算出した。図一5 は $\delta F_{X t F}$ と $\mathrm{rms} K \cdot C$ 数との関係を $\theta$ 毎にプロットしたものである.

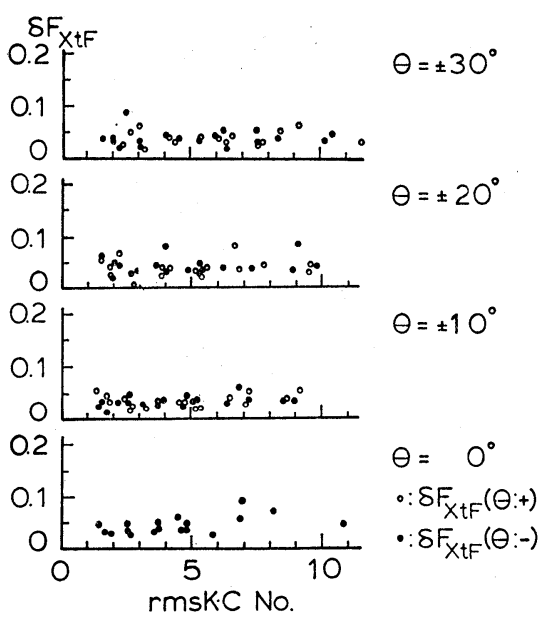

図一5 $F_{X t}(t)$ の $F_{X m}(t)$ からの分散度 (Time-dependentな係数を用いた場合）

この図から明らかな如く, $\delta F_{X t F^{\prime}}$ の值は $\theta$ および $\mathrm{rms} K \cdot C$ 数の值に関係なく, ほぼ一様に 数\%の值に低 下した。 このことから, time-dependent な係数值を用い れば（1)式はかなりの精度で in-line force を算定できる 事が判った。

（2）Transverse force 算定式の評価

図一6 は 3 点法掞よび最小自乗法より求めた各係数值 を用いて (2) 式から算出した transverse force, $F_{T t 3}(t)$ および $F_{T t l}(t)$ と実測 transverse force, $F_{T m}(t)$ の比較 例を示す.

全実験例について同様な比較を実施した結果，以下の 諸点が明らかになった。

a) $\operatorname{rms} K \cdot C$ 数がほぼ 3 以下の場合には, 全傾斜角 の場合とも transverse force はほとんど発生しない.

b) $\mathrm{rms} K \cdot C$ 数がほぼ 6 以上になると作用波のほぼ 2 倍の周波数を有する transverse force が発生するが， $F_{T t 3}(t)$ および $F_{T t t}(t)$ の双方とも， $F_{T m}(t)$ から大きく 外れる。 


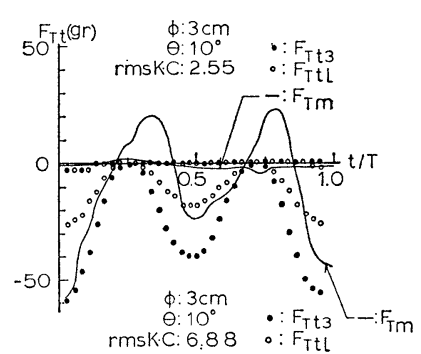

図一6 $F_{T t}(t)$ と $F_{T m}(t)$ の比較例 (Time-independent な係数值を用いた場合)

次いで両計算波力の実測值からの分散度, $\delta F_{T t}$ を(3) 式にならって算出した。図一7 は $\delta F_{T t}$ と $\mathrm{rms} K \cdot C$ 数との関係を $\theta$ 每にプロットしたものである. 図中, $\delta F_{T t 3}$ は $F_{T t 3}(t) の F_{T m}(t)$ からの, また $\delta F_{T t l}$ は $F_{T t t}(t)$ の $F_{T m}(t)$ からの各分散度を示す。この四から明らかな 如く, 両分散度は $\mathrm{rms} K \cdot C$ 数および $\theta$ の大きさに関係 なく, 平均して 100\% 程度の值となり，中には $200 \%$ にも達するものも見られる。
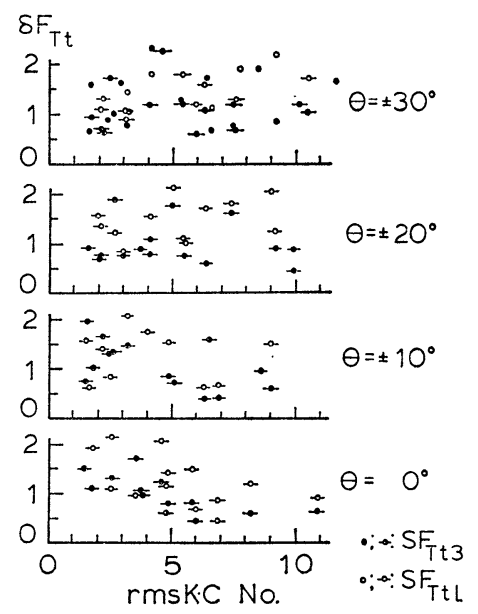

图一7 $F_{T t}(t)$ の $F_{T m}(t)$ からの分散度 (Time-independent な係数値を用いた場合)

一方，図一8 は前述のフーリエー級数に展開・近似さ せた各係数を用いて算出した transverse force, $F_{T t F}(t)$ そ $F_{T m}(t)$ との比較例を示す.

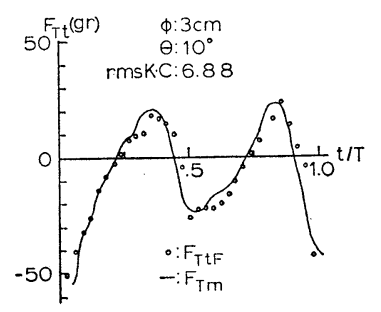

图一8 $F_{T t}(t)$ と $F_{T m}(t)$ との比較例 (Time-dependent な係数値を用いた場合）
全実験例について同様な比較を行なった結果, $F_{T t F}(t)$ は $\operatorname{rms} K \cdot C$ 数执よび $\theta$ の大きさに関係なく，周期内の ほぼ全位相に打いて $F_{T m}(t)$ とよく一致することが判っ た.

また，図一9 は $F_{T t F}(t)$ の $F_{T m}(t)$ からの分散度， $\delta F_{T t F}$ と $\mathrm{rms} K \cdot C$ 数との関係を $\theta$ 毎にプロットした ものである。この図から明らかな様に， $\delta F_{T t F}$ は全傾斜 角の場合とも約 $20 \%$ 以下になり, しかも $\mathrm{rms} K \cdot C$ 数 の増大に伴なって更に減少する傾向が見られた．このこ とは time-dependent な係数值を用いれば，(2) 式はか なりの精度で transverse force を算定し得ることを示し ているものと思われる。

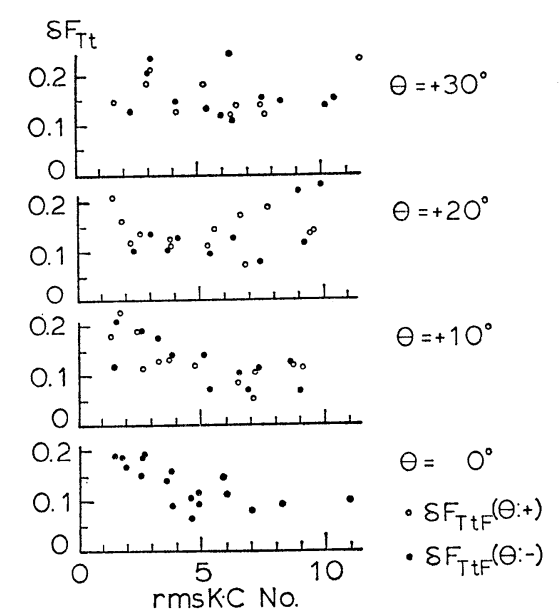

图一9 $F_{T t}(t)$ の $F_{T m}(t)$ からの分散度 (Time-dependent な係数を用いた場合）

\subsection{In-line force $と$ transverse force $の$ 比}

図一10 は 1 周期内で記録された $F_{X m}(t)$ の最大值に 対する $F_{T m}(t)$ の最大值の比, $R$ と $\mathrm{rms} K \cdot C$ 数との関 係を $\theta$ 毎にプロットしたものである.

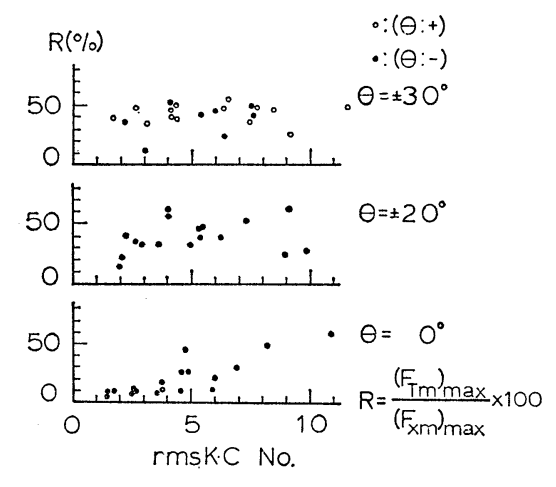

図-10 In-line force と transverse force の比

この図から以下の諸点が明らかになった。

a) 傾斜角が $10^{\circ}$ 以下の場合には $R$ の值は $\mathrm{rms} K \cdot C$ 数の増大に伴ない, ほぼ直線的に増大し, $\mathrm{rms} K \cdot C$ 数 
が 10 程度になると約 0.6 亿達する。なお, Bidde出は 直円柱に関する実験で同様な結果を得ている.

b) $\theta$ が $20^{\circ}$ 以上になると $R$ の值は $\mathrm{rms} K \cdot C$ 数の 大きさに関係なく，ほぼ 0.5 程度の一定值をとる.

\section{3 作用波と in-line force との位相差}

図一11 は作用波の波頂部が傾斜円柱の中心軸を通過 後, $F_{X m}(t)$ が最大になる安での位相差, $\Delta t$ と $\mathrm{rms} K \cdot C$ 数との関係を $\theta$ 毎にプロットしたものである.

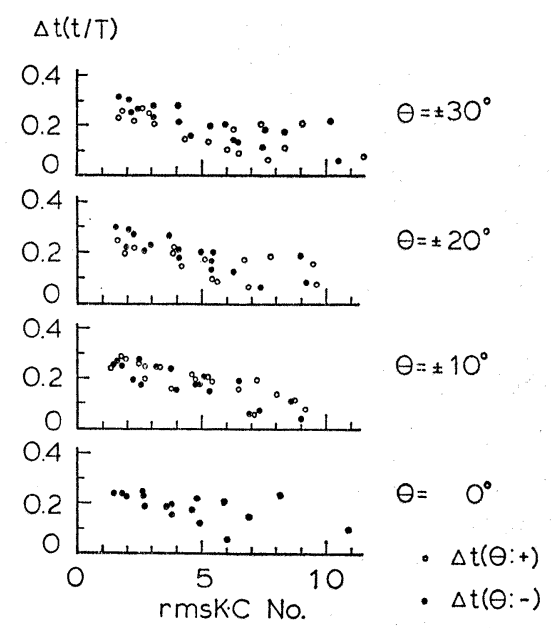

図-11 作用波と in-line force との位相差

この図から明らかな如く, $\Delta t$ は $\theta$ に関係なく, $\mathrm{rms} K \cdot C$ 数の増大に伴ないほぼ直線的に減小する. こ れは $\mathrm{rms} K \cdot C$ 数の增大に伴ない, $F_{X m}(t)$ 中に占める 慣性項の影響が減少するためと考えられる。

\section{5. 結論}

波峯線に平行な鉛直断面内に設置した傾斜円柱に作用 する 2 種の波力につき検討した結果, 以下の結論を得た.

1）両波力とも，数個の有意周波数項でフーリェ一級 数に展開・近似させた係数值を用いれば, モリソン式脰 よび揚力式に基づいて誘導した波力算定式からかなりの 精度で算定することができる.

2) In-line force に対する最大 transverse force の比 は, $\theta=0^{\circ}$ の場合には $\mathrm{rms} K \cdot C$ 数の增大に伴ないほぼ 直線的に增大し, $\mathrm{rms} K \cdot C$ 数が 10 近辺では約 0.6 に達 するが, $\theta$ が $20^{\circ}$ 以上になると同比は $\mathrm{rms} K \cdot C$ 数の大 きさに関係なく, ほぼ 0.5 程度の一定値をとる。

3）作用波の波項部が傾斜円柱の中心軸を通過後，同 円柱上に最大 in-line force が生ずるまでの位相差, $\Delta t$ は $\mathrm{rms} K \cdot C$ 数の增大に伴ない約 $0.3 T$ から $0.1 T$ まで, ほぼ直線的に減少する。

\section{参 考 文 献}

1）重村利幸 - 西村健二 - 竹内俊雄：傾斜円柱化作用する波力 そついて, 第 25 回海岸工学講演会論文集, pp. 367 371, 1978.

2) Shigemura, T. and Nishimura, K.: Simulation of wave forces on inclined cylindrical piles, Coastal Structure 79, ASCE, Vol. 1, pp. 134 153, 1979.

3) Al-Kazily, M. F.: Forces on submerged pipelines induced by water waves, University of California, Berkeley, Hydraulic Engineering Laborotory, Technical Report, HEL. 9-21, p. 197, 1972.

4) Bidde, D. D.: Laboratory study of lift force on circular piles, Proc. ASCE, WW4, pp. 595 614, 1971. 